\title{
Commercial break for Britain's science?
}

THE word 'atmosphere" liberally peppers the speech of Neil Macfarlane. It is used constantly in attempts to describe just how important good morale is for the country's scientific community, and in particular, the newly-appointed Minister for Science believes there must be infinitely better links between "the research atmosphere" of the good universities and industry in Britain.

"We have lost a lot of ground over the past 20 years now", he states. "Too many industrial organisations have turned to their companies' research activities when looking for savings on their annual budget." To rectify matters, he maintains that we must encourage companies to set up centres close to universities - as the Americans do. Similarly our universities must be more commercially minded in looking for closer ties with major firms.

But 43-year-old $\mathrm{Mr}$ Macfarlane stresses that the real effort must come from industry, which in the past has shown little regard for scientific and engineering talent. "I think it is greatly to be regretted that the engineer and the scientist are generally relegated to a secondary level in the hierarchy of any major industrial organisation in the UK. We have been taken over by financiers and lawyers."

These are candid words from a junior minister who has no scientific training and whose background is solidly commercial. Educated at Bancroft's School, Woodford Green, he was commissioned in the Essex Regiment from 1955 to 1957 . He left "afiter Suez, the Middle East and all that particular cafuffle" for the oil industry, to eventually become a sales manager with BP; he was closely involved in the 1973 oil crisis, dealing with the distribution of petrol in Southern England.

In February 1974, he was elected Conservative MP for Sutton and Cheam and straightaway sat on the Select Committee for Science and Technology. His experience there opened up a completely new interest in science and Mr Macfarlane is quick to defend the committee's record for giving a good overview of science and technology and for its many short, sharp investigations: "I think the whole atmosphere which then developed because of the decline of our industry prompted many of us to pursue various technological issues with vigour and at all levels."

$\mathrm{He}$ is certainly no supporter of the proposal by the Select Committee on Procedure for the dissolution of the science and technology group. "I

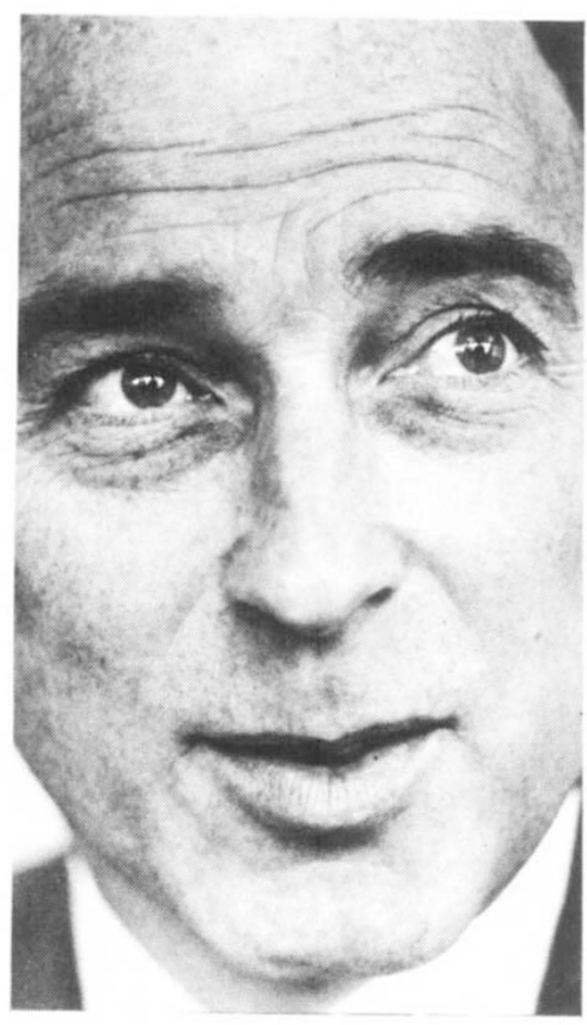

Neil Macfarlane (above),

Minister for Science in the new Tory government, wants closer ties between industry and research

\section{Profile by Robin McKie}

would be very apprehensive if it was entirely disbanded because I would envisage a tremendous amount of duplication of its work by other government departments." But defenders of the committee cannot look to him as an ally in their fight for its retention, because he maintains that, as a member of the government, he has no right to intervene in a purely House of Commons matter.

Even if the committee is disbanded, Mr Macfarlane will remain optimistic, believing that in general both parliament and government serve science well. "I just wish that we could have a little more motivation of other Members of Parliament towards the importance of science. There is not nearly the interest that there should be." He believes the previous Labour administration did not help by giving all responsibility for science to the Secretary of State for Education and Science, Mrs Shirley Williams, without delegating to a junior minister. Education became such a political football that it took up most of her time, at the expense of science.

"However, I am not going to criticise her all the way because I think in many respects she did show a tremendous interest and grasp, and doubtless she would have liked to have spent more time on science. But now there is someone who can spare that time and has access straight through to the Secretary of State who is totally involved himself. We have got to ensure that the science fraternity knows. it is not neglected by this administration."

This desire is reflected in the breadth of Mr Macfarlane's role, which covers science, research, technology, engineering and preparing for the advent of the microprocessor revolution. Although there have been junior ministers for science before, they have not been faced with the same sweep of responsibilities.

One major problem is staff stagnation at university science departments, which is freezing promotions, preventing staff exchanges between centres and hindering the cross-fertilisation of ideas. Mr Macfarlane refuses to be pessimistic, however. "I don't entirely take a gloomy view of staff stagnation. It was probably bad eight or 10 years ago, maybe even four or five but I believe there has been a great awakening over this problem in recent years. Things are beginning to move and there is this exchange and crossfertilisation taking place. We have just got to accelerate it somehow."

In general, he foresees "a period of stabilisation" for universities, with the emphasis being placed on training the 16-19 age group to provide skilled technician manpower for our industrial re-birth. The research coundils can expect to continue with the level of funding which has occurred in the past couple of years.

On the horny question of lay and union representation on the laboratory safety committees the Dangerous Pathogens Advisory Group and the Genetic Manipulation Advisory Group, Mr Macfarlane takes the same steadfast line as his Secretary of State, Mr Mark Carlisle, in opposing such moves. "These two bodies are so highly specialised that I don't believe there is a role for anybody else on them at this embryonic stage of their activities."

The real problem is using science properly in our industrial growth. "The main thing at the moment is that the atmosphere is right in the science departments-whereas five to 10 years ago it was very different. What I want to do is make Britain proud of its science, and that is going to be quite easy because our science is second to none. It is the very best." 